\title{
Appropriate integration of geothermal energy sources by Pinch approach:
}

\section{Case study of Croatia}

\author{
Alae-Eddine Barkaoui ${ }^{1,2}$, Stanislav Boldyryev ${ }^{1}$, Neven Duic ${ }^{1}$, Goran Krajacic ${ }^{1}$, \\ Zvonimir Guzović ${ }^{1}$
}

${ }^{1}$ Faculty of Mechanical Engineering and Naval Architecture, University of Zagreb, Ivana Lučića 5, 10000 Zagreb, Croatia.

${ }^{2}$ Laboratory of mineral deposit, Hydrogeology and Environment, Faculty of Sciences, University Mohamed I ${ }^{\text {st }}$, Oujda, Morocco

Mob: 00212666110244, abarkaoui@fsb.hr

\begin{abstract}
Geothermal energy is a widely available renewable energy source. In Croatia geological data has been indicating promising potential, especially in the North-Eastern part of the country with a geothermal gradient higher than $49^{\circ} \mathrm{C} / \mathrm{Km}$ and terrestrial heat flux of $76 \mathrm{~mW} / \mathrm{m}^{2}$. Nonetheless, despite this potential, this resource is not highly exploited to date. Efficient use of geothermal energy can contribute on reducing Croatia's energy dependence.
\end{abstract}

In this paper, a methodology of a possible integration of geothermal energy within residential, commercial and industrial systems was attempted. Pinch analysis was used to find the best ways to fulfil the energy system requirements in an efficient, clean and cost-effective way. The used approach gives a good overall picture of energy targets for process, site and utility levels. The recommendation for cost-effective integration of geothermal energy into regional energy network is considered by use of Pinch Analysis. Additional attention was paid to geothermal energy utilization in low enthalpy sedimentary environments. The obtained results can be used for integration of geothermal energy in different cases and "countries". It gives 
general recommendation for geothermal sources placement as well as for energy planning and regional sustainability.

\section{KEYWORDS}

Geothermal energy, Energy management, Integration of renewables, Pinch Analysis, Sustainability

\section{INTRODUCTION}

The world is facing an era of expensive energy supply, which requires an adaptation of policies and country strategies. It has not only greatly increased the costs but also environmental, social and political impact of all energy using activities. With this situation, the use of geothermal energy has gained interest. This resource is used for electricity production as well as for direct use. Around the world, the benefits of direct geothermal use are well demonstrated. The environmental and economic impacts can be felt in countries where this energy source is used. Direct geothermal utilization is related to a set of applications depending on the temperature of the geothermal fluid. This resource can be used to heat homes, greenhouses, fish farms, gold mining operations, food processing facilities, and a variety of other applications (Figure1). Other options can be linked to the cascaded utilization where the fluid from geothermal electric plants is used. This operation ensures efficient and cost effective utilization of the available energy. In 2014, the total installed capacity for geothermal direct utilization worldwide is around $70.329 \mathrm{MW}$, and the total annual energy use is 587.786 TJ (163.287 GWh) [1].

In Croatia geological data has been indicating promising potential, especially in the Pannonian basin in the North-Eastern part of the country. Geothermal field of Velika Ciglena is identified as one of the most valuable geothermal heat sources and probably the location where the first 
geothermal plant in the Western Balkan area will be built with an installed power generation capacity of 4.71 MW [2]. Until now geothermal energy is mainly used in spas, bathing and swimming, and for space heating. This energy is used also to heat greenhouses. The individual uses of geothermal energy are 31.99 MW and 291.79 TJ/y for individual space heating, 13.77 MW and 8.61 TJ/y for district heating, 7.53 MW and 169.49 TJ/y for greenhouse heating, 22.15 MW and 172.1 TJ/y for bathing and swimming, 4.50 MW and 42.50 TJ/y for geothermal heat pumps. The total for the country is $79.94 \mathrm{MW}$ and $684.49 \mathrm{TJ} / \mathrm{y}$ [3].

Geothermal energy sources can produce a considerable amount of low potential heat, which usually cannot be used $[4,5]$. From other side industrial sites consume huge amount of natural resources, mostly hydrocarbons, for heating and it is then rejected to the atmosphere through a water and air cooling systems. In [6], authors assesses the potential for the integration of geothermal energy combined with biomass in the energy system of a city, taking into account the consumption of fossil and renewable resources, costs and environmental impact. For geothermal energy, deep aquifers and Enhanced Geothermal Systems are considered, for separate production of heat and electricity, and cogeneration. A problem in exploiting renewable energy sources is their fluctuating availability as shown in [7] and Heat Integration methodology for batch processes based on Time Slices (TS) was extended. Two approaches to identify the size and number of TS for variable renewable supply are investigated. The optimal integration of renewable energy needs a trade-off between investment and operating cost. Barkaoui et al [8] concluded that, in general, the evaluation of the financial aspects for the development of a geothermal system depends strongly on a proper site characterization and described the trade-off on the case of North Eastern Morocco, where an area with a significant geothermal potential is available. Nevertheless, there is a lack of publication on geothermal energy usage for industrial systems in a systematic way. 
Industrial systems are very complicated objects with big amount of process streams that should be heated and cooled. It is difficult to obtain an optimal solution without a detailed analysis of process streams, its potential, efficient recuperation and heat transfer on different levels of temperature. An advanced methodology for the achievement of optimal energy efficiency is Process Integration [10]. This methodology has considerable potential in the food processing industry, as it was demonstrated in several publications by different authors [11].

Process Integration has been started from 70s of previous century. It has been related to the development of engineering approaches for process and utility systems to energy, water and resources savings. Historical development, achievements and future challenges were highlighted by Klemeš, J.J. and Kravanja, Z. [12]. Pinch Analysis is used in different areas, from specific industrial applications to power systems. . For example, a new graphical method, based on Pinch Analysis, for the grassroots design of heat exchanger networks was presented in [13]. Network design achieved by this technique guarantees maximum heat recovery. The new technique can also be employed to simulate basic designs of heat exchanger networks. In [14] carbon emission Pinch Analysis is considered. Method has been modified for improved application to large transport systems. The modified method is applied to investigate the feasibility of New Zealand reaching a 1990 emission levels for transport by 2050. Grip et al [15] studied an integrated steel plant. This study confirmed that Pinch Analysis is a powerful tool for targeting energy savings in areas where thermal energy flows dominate the local energy system, e.g., the gas cleaning area at the coke plant. Another industrial application presented in [16] providing Process Integration of a bioprocess plant which produces yeast and ethyl-alcohol. It is shown that the heat recovery system without a heat storage opportunity can be considered to be more profitable solution for the energy efficiency increase in a plant. New heat recovery and power targeting models were developed in [17]. The authors demonstrated practical limits such as steam mains superheat and turbine 
exhaust dryness and improved the accuracy of the targeting, and overcome the shortcomings of previous targets. The combination of different methods was used for utilities pre-design in [18]. The authors proposed a preselection algorithm for utilities, focused on chillers, heat pumps, Organic Rankine Cycles (ORC) units and Combined Heat and Power (CHP) units. The Pinch Analysis was used to provide initial data such as the Grand Composite Curve. The mentioned theoretical developments are not supplemented by proper applications of the methodology for industrial application of GES in a proper and systematic ways.

This paper presents an approach for the integration of geothermal energy sources into industrial sector and the case study for Croatian industrial system is demonstrated. The used approach gives a systematic view on energy targets for process, site and utility levels. The method is based on Process Integration principles identifying process streams that are heated or cooled by utility in order to find possibilities for increased integration between utility systems.

\section{GEOTHERMAL RESEARCH IN CROATIA}

Around the world, energy markets are not driven only by demand and supply. Political and social issues control also the provision of energy for the present and the future. In this context, Croatia has declares itself to use all kind of renewable energy sources in accordance with the principles of sustainable development. The main goal is to reach around $84 \mathrm{PJ}$ of renewable energy sources in 2020 (Figure 2). Geothermal research in Croatia started since 1976. The basis of these studies were the analyzed of data obtained from the oil and natural gas exploration.

Geologically, two sedimentary basins cover almost the entire territory of the Republic of Croatia (Figure 3). In the "Dinarides" basin the average geothermal temperature gradient and heat flux are respectively $0.018{ }^{\circ} \mathrm{C} / \mathrm{m}$ and $29 \mathrm{~mW} / \mathrm{m}^{2}$. Unlike this part of the country, which 
has no significant geothermal potentials, the average geothermal temperature gradient and heat flux in the "Pannonian" basin are around $0.049{ }^{\circ} \mathrm{C} / \mathrm{m}$ and $76 \mathrm{~mW} / \mathrm{m}^{2}$. Those values are considerably higher than the European average values.

Geothermal energy is already used in Croatia for medical purposes and bathing. In addition to natural springs, geothermal waters are exploited from shallow bores. The purpose of initial exploration was to process data obtained in exploration bores with the aim of finding oil and gas reserves. Regarding electricity production using geothermal energy, the most important project is located at the Velika Ciglena region with an installed power generation capacity of 4.71 MW. This geothermal field is identified as one of the most valuable geothermal heat sources in the Western Balkan area. The main objective of the project is to develop business zone where the thermal power plant will be in a situation to stimulate electricity prices and then to offer businesses in this zone at favorable price to attract potential investors.

\section{METHODOLOGY FOR INTEGRATION OF GES IN INDUSTRY}

Since geothermal energy was used for industrial and utility needs it has a lot of applications in different sectors, it is mostly low temperature processes. Basically the selection of GES is provided by target temperature of media which should be heated.

Barkaoui et al. 2013 [8] highlighted the temperature levels of different industrial needs and the amount of geothermal energy that can be integrated for different drilling deep. But the processing industries have complicated stream systems with multiple heating and cooling, recovery and utilities. The use of low potential energy sources for such type of systems have to be done properly after detailed analysis [21]. In this paper the authors propose a methodology for appropriate integration of GES into industrial processes to reduce the operation costs and increase share of renewables. This is especially important for industrial units which have a lack of energy sources and high energy prices. 


\subsection{APPROPRIATE PLACEMENT OF GES INTO INDUSTRIAL SYSTEM}

The proposed methodology is based on thermodynamic approach and use Pinch Analysis as main tools which is now well developed and implemented [22, 23]. The key idea is to analyse the stream system including the GES in proper way in order to reduce utility heat load. It is possible to make such measures with use of Composite Curves.

In the Fig. 4a typical composite curves of industrial process are shown. The GES can be included as the hot stream with supply temperature from the well ( $\left.\mathrm{T}_{\mathrm{S} G E O}\right)$ and target temperature of reinjection to the underground storage $\left(\mathrm{T}_{\mathrm{T} G E O}\right)$. Depending on these temperatures the GES is placed relative to Pinch point. If GES is situated in subsystem below the Pinch as shown on Fig. 4b it leads to increase of cold utility on heat load of GES (Q $\left.\mathrm{Q}_{G E O}\right)$. This placement is not appropriate and there no sense to use geothermal energy for such processes. If supply and target temperatures of GES above the Pinch temperature the GES will be situated in subsystem above the Pinch and increase the heat recovery of the process.

The Fig. 4c shows the placement of GES above the Pinch point. In this case hot utility is reduced on heat load of GES $\left(\mathrm{Q}_{G E O}\right)$. During this integration the heat load of GES should strive to hot utility load to minimise the last one:

$Q_{G E O}=\lim _{n \rightarrow Q_{\mathrm{H} \text { min }}} n$

The maximum flow rate of GES which is needed to satisfy hot utility demands can be obtained from question 2:

$G_{G E O}^{\max }=\frac{Q_{\mathrm{H} \min }}{\left(C_{\mathrm{P} G E O} \times\left(T_{\mathrm{S} G E O}-T_{\mathrm{T} G E O}\right)\right)}$

So, the hot utility demands of industrial process can be totally satisfied by GES in case of integration above the Pinch point. But there are some limitations for maximisation of GES 
flowrate. Firstly, the process conditions, temperatures and flowrates which form the subsystem above the Pinch. The configuration of Composite Curves cannot afford to do so. Secondly, the Pinch point position limits the target temperature of GES. If target temperature of GES is less than the hot Pinch temperature, the cold utility should be increrased as shown in Fig.4b, which is useless. Thirdly, it is limited by reduced capacity of GES, if the hot utility demands are bigger than the obtained heat from well(s). In this case maximum GES flowrate cover part of hot utility demands.

\section{2. . INTEGRATION OF GES IN COMBINATION WITH HEAT PUMP}

As was said above, the integration of GES below the Pinch point is useless if GES is accounted as process or utility stream, but situation can be changed in case of application of heat engines. Analysing some industrial process it is possible to use low potential heat on higher temperature levels. It can be done with use of heat pumps [25] and utility analysis by Grand Composite Curve (GCC).

Let's consider the case with heat pump application to reduce the energy consumption. On the Fig. 5a the GCC of the industrial process is shown. There is a possibility to install the heat pump according to Pinch rules [26] across the Pinch. It leads to reduction of hot and cold utilities on the heat pump capacity $\left(\mathrm{Q}_{\mathrm{HP} 1}\right)$ but it is needed to add power shaft of compressor $\left(\mathrm{W}_{1}\right)$ as shown on Fig. 5b. The heat load utilisation, in this case, is limited by heat recovery pocket below the Pinch. But during the integration of GES below the Pinch point the situation can be changed and heat capacity of heat pump is increased. The use of GES below the Pinch increases the capacity of heat but it is useful if there is a consumer above the Pinch (Fig. 5c). This placement of GES in combination with heat pump reduces initial hot utility demands $\left(\mathrm{Q}_{\mathrm{H} \text { min }}\right)$ on new capacity of heat pump $\left(\mathrm{Q}_{\mathrm{HP} 2}=\mathrm{Q}_{\mathrm{HP} 1}+\mathrm{Q}_{G E O}\right)$ which bigger than in first case on GES capacity $\left(\mathrm{Q}_{G E O}\right)$. But in this case, the power shaft work of compressor is increased $\left(\mathrm{W}_{2}\right)$. 
During integration the GES below the Pinch the flow rate of GES is limited by the well capacity from one side and by the target temperature of return geothermal $\left(\mathrm{T}_{\mathrm{T} G E O}\right)$ water which cannot be less than temperature of recovery pocket (Temperature limit in Fig. $5 \mathrm{c}$ ). The flow rate of geothermal water in case of integration below the Pinch in combination with heat pump is calculated from equation (3):

$G_{G E O}=\frac{Q_{G E O}}{\left(C_{\mathrm{P} G E O} \times\left(T_{\mathrm{S} G E O}-T_{\mathrm{T} G E O}\right)\right)}$

In addition it should be noted that this integration is possible after detailed process analysis and finding the appropriate pathways.

\section{CASE STUDY FOR CROATIA}

There is a reprocessing of vegetable oil in considered case study. The existing process is based on purification of raw vegetable oil with obtaining of product without impurities that are consisted from light organic substances.

21 process streams with specific phase and thermo-physical properties were extracted and included to heat integration. These streams were collected in the Table 1. Composite Curves of existing process were built with use of data in Table 1 and shifted to create heat recovery (Fig. 6). The existing process is well integrated and minimum temperature approach of analysed process is $15^{\circ} \mathrm{C}$, the heat recovery is represented by overlapping part of Composite Curves. Hot and cold utility consumption are $772 \mathrm{~kW}$ and $665 \mathrm{~kW}$ respectively.

The geothermal energy source, in this case, has the supply temperature $99{ }^{\circ} \mathrm{C}$ and target temperature of reinjection to the underground storage is $78^{\circ} \mathrm{C}$. Let's consider the possibility to use this geothermal energy source for industrial need to heating demand. Geothermal Energy is included to hot process streams with temperature level $\left(99-78{ }^{\circ} \mathrm{C}\right)$ and flowarte 
6.4 L/s. The later is calculated from equation (2). Composite Curves with GES stream were built in order to get new targeting of industrial process.

\section{RESULTS AND DISCUSSIONS}

Considering the possibility to integrate the geothermal water it is important to define Pinch Point placement. Composite Curves show the Pinch temperatures are $30{ }^{\circ} \mathrm{C}$ and $15{ }^{\circ} \mathrm{C}$ for hot and cold streams respectively (see Fig. 6). It is possible to integrate the geothermal energy source with temperature level $\left(99-78^{\circ} \mathrm{C}\right)$ as it will be located above the Pinch Point. Applying the methodology mentioned above the flowrate of geothermal water can be calculated from equation (2). Nevertheless, maximum flow rate of geothermal water will be limited by composite curves configuration and it is not possible to cover all heating capacity by geothermal source. The Composite Curves with stream of geothermal water are show in Fig. 7, minimum temperature approach is kept $15^{\circ} \mathrm{C}$. This temperature approach will be used for further integration of GES because changing of this parameter is required to rebuild existing heat exchangers network.

Increasing the geothermal water flow rate the utility Pinch is appeared. The flow rate can be increased until this point will be less than $15^{\circ} \mathrm{C}$, at the same time hot utility is reduced while the cold utility is constant. Further increasing of geothermal water flow rate leads to growing up the cold utility and the hot utility is not changed. In this case study, integration of geothermal energy source leads to two Pinch problems. The optimal flow rate of geothermal water is $6.4 \mathrm{~L} / \mathrm{s}$. Heat integration of geothermal water of such flow rate allow reducing the process hot utility at $563 \mathrm{~kW}$. The cost of hot utility is $366 \mathrm{EUR} / \mathrm{kWy}$ that corresponds to prices of natural gas for Croatian industry in 2014 [27], 8318 working hours and $10 \%$ of heat losses. The heat integration of geothermal energy source to vegetable oil reprocessing gives 
the annual saving at 206,058 EUR but this point has to be additionally discussed in scope of retrofit application.

The retrofit project will face some technical limitation while applying new heat exchangers network for increased recovery. It means minimising the heat transfer area and optimisation of network topology to reduce the investment and payback time. This point is very important for implementation of investment roadmap and energy management system of plant owners and Croatia energy planning strategy.

\section{CONCLUSIONS}

The paper developed a methodology for appropriate integration of geothermal energy sources of industrial systems. The Pinch Analysis approach was adopted in order to define the best ways to fulfil the energy system requirements in an efficient and cost-effective way. The methodology allows the identification of the useful flow rate of geothermal water for industrial integration.

The case study analysed the possibility of the integration of geothermal energy sources to Croatian vegetable oil reprocessing factory. The use of geothermal heat provides a way to reduce the primary energy consumption and to contribute to global $\mathrm{CO}_{2}$ mitigation. The optimal flow rate of geothermal water has been calculated and general recommendations were outlined. Factory heating demands is covered by GES on $72.9 \%$ while cooling capacity is not changed. This case study shows that the share of renewable energy sources could cover big part of low temperature industrial sector but proper analysis is required.

The results of this work can be used for retrofit of Croatian industrial sites as well as other countries. The results of this work have a diversified effect because it gives 
the recommendations for geothermal energy mapping and usage that has a direct influence to energy planning, regional sustainability and energy market.

\section{ACKNOWLEDGMENTS}

The authors would like to acknowledge the financial support by the EC and Croatian Ministry of Science Education and Sports projects "INTERGEORES" and "CARBEN" (NEWFELPRO Grants Agreements No. 43 and 39 )

\section{NOMENCLATURE}

$\mathrm{C}_{\mathrm{PGEO}}$ - isobaric heat capacity of geothermal water, $\mathrm{kJ} /\left(\mathrm{kg} \times{ }^{\circ} \mathrm{C}\right)$;

GES - geothermal energy source;

$\mathrm{G}_{G E O}$ - flow rate of geothermal water, $\mathrm{kg} / \mathrm{s}$;

$G_{G E O}^{\max }-$ maximum flowrate of geothermal water, $\mathrm{kg} / \mathrm{s}$;

$\mathrm{H}$ - enthalpy, kW;

QHmin - hot utility, kW;

$\mathrm{Q}_{\mathrm{Cmin}}$ - cold utility, $\mathrm{kW}$;

QHP1 - capacity of heat pump, kW;

QнР2 - capacity of heat pump with integration of geothermal energy, $\mathrm{kW}$;

$\mathrm{Q}_{G E O}$ - capacity of geothermal energy source, $\mathrm{kW}$;

$\mathrm{T}_{\mathrm{SGEO}}$ - supply temperature of geothermal water, ${ }^{\circ} \mathrm{C}$;

$\mathrm{T}_{\mathrm{T} G E O}-$ target temperature of geothermal water, ${ }^{\circ} \mathrm{C}$;

$\mathrm{T}^{*}-$ shifted temperature, ${ }^{\circ} \mathrm{C}$;

$\mathrm{T}$ - temperature, ${ }^{\circ} \mathrm{C}$;

$\mathrm{W}_{1}$ - power of heat pump, $\mathrm{kW}$;

$\mathrm{W}_{2}$ - power of heat pump with integration of geothermal energy, $\mathrm{kW}$; 


\section{REFERENCES}

1. Lund J.W., Boyd T.L. Direct Utilization of Geothermal Energy 2015 Worldwide Review, Proceedings World Geothermal Congress, Melbourne, Australia, 19-25 April 2015.

2. Guzović Z., Majcen B., Cvetković S. Possibilities of electricity generation in the Republic of Croatia from medium-temperature geothermal sources. Applied Energy, Volume 98, October 2012, Pages 404-414.

3. Kolbah S., Živković S., Golub M., Škrlec M. Croatia Country Update 2015 and On, Proceedings World Geothermal Congress, Melbourne, Australia, 19-25 April 2015.

4. Kwak D.H., Binns M., Kim J.K. Integrated design and optimization of technologies for utilizing low grade heat in process industries. Applied Energy, Volume 131, 15 October 2014, Pages 307-322

5. Liu Q, Shang L, Duan Y. Performance analyses of a hybrid geothermal-fossil power generation system using low-enthalpy geothermal resources. Applied Energy 162 (2016) $149-162$

6. Moret S., Gerber L., Amblard F., Peduzzi E., Maréchal F. Geothermal Energy and Biomass Integration in Urban Systems: a Case Study, PROCEEDINGS of Fourtieth Workshop on Geothermal Reservoir Engineering, Stanford University, California, January 26-28, 2015.

7. Nemet A., Klemeš J.J., Varbanov, P.S., Kravanja, Z. Methodology for maximising the use of renewables with variable availability, Energy, Vol. 44, Issue 1, pp 29-37, 2012.

8. Barkaoui A., Nemet A., Varbanov P. S., Klemeš J. J., Zarhloule Y., Rimic A. Integration of Geothermal Energy in the Case of North Eastern Morocco, Chemical Engineering Transactions, Vol. 32, pp 247-252, 2013.

9. Lindal, B. Industrial and other applications of geothermal energy. In B. Lindal, Industrial and other applications of geothermal energy (pp. 135-148). Paris: UNESCO. 1973. 
10. Klemeš J. J., Varbanov P. S., Wan Alwi S. R., Manan Z.A., Process Integration and Intensification Saving Energy, Water and Resources. De Gruyter, 2014.

11. Klemes $`$ J., Perry S. Process optimisation to minimise energy use in food processing. In: Waldron K, editor. Handbook of waste management and co-product recovery in food processing, vol. 1. Cambridge, England: Woodhead Publishing Limited; pp 59-89.

12. Klemeš J.J., Kravanja Z. Forty years of Heat Integration: Pinch Analysis (PA) and Mathematical Programming (MP), Current Opinion in Chemical Engineering, Vol. 2, No 4 , pp 461-474, 2013

13. Gadalla M. A. A novel graphical technique for Pinch Analysis applications: Energy Targets and grassroots design, Energy Conversion and Management, Vol. 96, pp 499-510, 2015

14. Walmsley M.R.W., Walmsley T.G., Atkins M.J., Kamp P.J.J., Neale J.R., Chand A. Carbon Emissions Pinch Analysis for emissions reductions in the New Zealand transport sector through to 2050, Energy, doi:10.1016/j.energy.2015.04.069.

15. Grip C.E., Isaksson J., Harvey S., Nilsson L. Application of Pinch Analysis in an Integrated Steel Plant in Northern Sweden, ISIJ International, Vol. 53, Issue 7, pp 1202-1210, 2013.

16. Anastasovski A., Rašković P., Guzović, Z. Design and analysis of heat recovery system in bioprocess plant, Energy Conversion and Management, 2015, doi:10.1016/j.enconman.2015.06.081.

17. Sun L., Doyle S., Smith R. Heat recovery and power targeting in utility systems, Energy, Vol. 84, pp 196-206, 2015.

18. Thibault F., Zoughaib, A., Pelloux-Prayer, S. A MILP algorithm for utilities pre-design based on the Pinch Analysis and an exergy criterion, Computers and Chemical Engineering, Vol. 75, , Pages 65-73, 2015.

19. The Republic of Croatia, Ministry of Economy, Labour and Entrepreneurship. Draft of the energy strategy of the republic of Croatia. Zagreb, June 2009. 
20. Kurevija T., Vulin D., Krapec V. Influence of Undisturbed Ground Temperature and Geothermal Gradient on the Sizing of Borehole Heat Exchangers. Linköping, Sweden, 8-13 may 2011.

21. Gerber L., Maréchal F. Defining optimal configurations of geothermal systems using process design and process integration techniques," Applied Thermal Engineering., vol. 43, pp. 2941, Oct. 2012.

22. Handbook of Process Integration (PI): Minimisation of Energy and Water Use, Waste and Emissions. Editor: Klemeš J.J. Woodhead Publishing, 2013

23. Klemes J.J., Friedler F., Bulatov I., Varbanov P.S. Sustainability in the Process Industry: Integration and Optimization (Green Manufacturing \& Systems Engineering) McGraw-Hill Education, 2010.

24. Linnhoff B., Townsend D.W., Boland D., Hewitt G.F., Thomas B.E.A., Guy A.R., Marsland R.H. User guide on process integration, last edition 1994. Rugby: IChemE; 1982.

25. Reay D.A., Macmichael D.B.A. Heat pumps: design and applications. Oxford: Pergamon Press; 1988.

26. Smith R. Chemical process design and integration. Chichester, England: Wiley; 2005.

27. Eurostat. Electricity and natural gas price statistics <ec.europa.eu/eurostat/statisticsexplained/index.php/Electricity_and_natural_gas_price_statistics>, accessed on 25.04.2015. 